\title{
Modernization process in the higher education system
}

\author{
Vasieva D.I. ${ }^{1}$ \\ ${ }^{1} \mathrm{PhD}$, Associate professor, Karshi Engineering-Economics Institute, Uzbekistan \\ Email:vasieva_d@umail.uz
}

\begin{abstract}
This paper makes analyses of the modernization process in the higher education system. On this case, Uzbekistan has been investigated in the article at all. Moreover, research has been focused on the modernization process in the case of the Republic.
\end{abstract}

Keywords: Modernization, process, higher education, system, research, Uzbekistan.

\section{INTRODUCTION}

The Law of the Republic of Uzbekistan "On Education" and "National Program for Personnel Training" define priority areas for continuous education system reform, improving the quality of educational work, training of competitive specialists, and the formation of creativity in future specialists. The social and economic reforms in the country are also being gradually implemented. At present, the legal and regulatory framework for education is established in the country, and these issues are identified as priority areas of public policy. Humanitarian and democratic nature of education and upbringing The task of continuous education is to prepare competitive personnel that meet the requirements of the market economy. It will also improve the educational process of higher education institutions, improve the quality of specialist training, improve the professional competence of teachers, equip them with modern professional knowledge, skills and abilities in the field, use creative scientific and technological innovations and solve promising tasks. development issues are one of the priority tasks today.

\section{THEORITICAL BACKGROUND}

As with all reforms in our country, the historical changes in this area are carried out under the direct initiative and under the guidance of the head of our state. As our president Sh.M. Mirziyoev noted: Our nation has a wise saying that "education and training start from the cradle". Only enlightenment can lead a person to perfection and to society. Therefore, it was emphasized that the state policy in education should be based on the principle of continuous education, that is, education must begin at kindergarten and last a lifetime. In particular, the Decree of the Republic of Uzbekistan "On Measures to Further Improve the System of Retraining and Advanced Training of Higher Education Institutions" is a clear proof of our opinion. Particular attention is paid to the training of highly qualified scientific personnel, namely: Presidential Decree No. UP-4907 "On Measures for Further Development and Promotion of Academicians of the Academy of Sciences of the Republic of Uzbekistan" and "On Further Improvement of Postgraduate Education System". Decrees of the President of the Republic of Uzbekistan won the attention and practical expression to occur as we all know. It is precisely based on these laws that a modern model of education that meets modern requirements has been formed in our country, and its effective activity is recognized not only in ourselves but also globally. Decree of the President of the Republic of Uzbekistan "On Measures for Further Development of Higher Education" to radically improve the system of higher education, to radically revise the essence of personnel training in accordance with the priorities of social and economic development of the country, to prepare highly qualified specialists in accordance with international standards. adopted in order to create necessary conditions and based on this resolution the basis for modernization and training of higher education in the country Large-scale work on introduction of traditional forms and technologies, improvement of specialization directions on preparation of specialists is carried out. 


\section{MAIN PART}

Based on the study of the state of higher education by the working group, adopted by the Decree of the President of the Republic of Uzbekistan № F-4724 dated October 8, 2016, a number of higher education institutions still have low scientific and pedagogical competence. A number of shortcomings have been identified, such as the need for upgrading their logistics system.

With a view to addressing the above disadvantages, the "Comprehensive Development Program of Higher Education for the period of 2017-2021", aimed at the priorities of socio-economic development of the country, has identified measures for the training of highly qualified personnel in accordance with the standards.

Effective implementation of these measures, above all, requires modernization of the higher education system. The current state of higher education in the Republic shows the need to organize the education system at the level of international standards, to integrate it into the international education system, to create a system of training for the needs of the modern international labor market.

Also, the Presidential Decree of February 7, 2017 "On the Strategy of Action for the Further Development of the Republic of Uzbekistan" outlines a number of tasks to improve the social sphere, in particular, education and science. The document envisages provision of modern educational and laboratory equipment, computer equipment, educational and methodical manuals along with strengthening of material and technical base of educational institutions, construction of new educational institutions, reconstruction and capital repairs of existing ones. In 2017-2021, the independence of higher education institutions will be gradually enhanced by developing a program to radically improve the system of higher education, further upgrading the curricula, and expanding the competence of higher education institutions in seeking additional sources of funding.

In line with the National Program for Personnel Training, tasks aimed at upgrading and enhancing the professional knowledge and skills of specialists have been implemented. Also, in accordance with the requirements of the time, the President of the Republic of Uzbekistan signed a decree on May 28, 2012 "On the training of qualified teachers and secondary special and vocational education." Decree of the President of the Republic of Uzbekistan dated December 10, 2012 "On measures for further improvement of the system of staffing of institutions" The measures on "a-activities" have led to a gradual and gradual implementation of the system of advanced training and retraining in accordance with the National Program for Personnel Training in the country.

At the same time, a legal mechanism has been created to improve the skills and retraining of personnel, their ability to speak foreign languages and to co-operate with many countries around the world. Also, according to the Decree of June 28, 2013 "On measures to further improve the legal training system", the country is focused on the preparation of highly qualified legal personnel that meet the highest international standards and democratic and legal reforms, the formation of civil society. important.

\section{CONCLUSION}

Currently, the process of informing the educational process on the basis of modern information technologies, computerization and computer networks is developing in the country. In particular, the role of the media in the learning process has increased. Intelligence of television and radio education programs is provided. The publishing base of science and education is developed, a stable system of providing educational, educational and methodical, scientific, encyclopedic literature and directories is being formed.

In short, the ongoing reforms in the education system in our country have a great role in training young people to compete in the labor market, to become professionals who can do great work for their future and future, to bring the Uzbek people closer to the world.

\section{REFERENCES}

1. Mirziyoev Sh. Address to the Parliament on the Priorities for 2019

2. Mirziyoev Sh. Critical analysis, strict discipline, and personal accountability should be the daily routine of every leader. T.- "Uzbekistan”, 2017. 
3. The Decree of the President of the Republic of Uzbekistan dated December 29, 2016 № UP-4907 "About measures for further development and stimulation of activity of academicians of the Academy of Sciences of the Republic of Uzbekistan"

4. Decree of the President of the Republic of Uzbekistan "On the Strategy of Action for the Further Development of the Republic of Uzbekistan" No. UP-4947

5. Decree of the President of the Republic of Uzbekistan dated February 16, 2017 "On further development of postgraduate education" No. UP-4958 